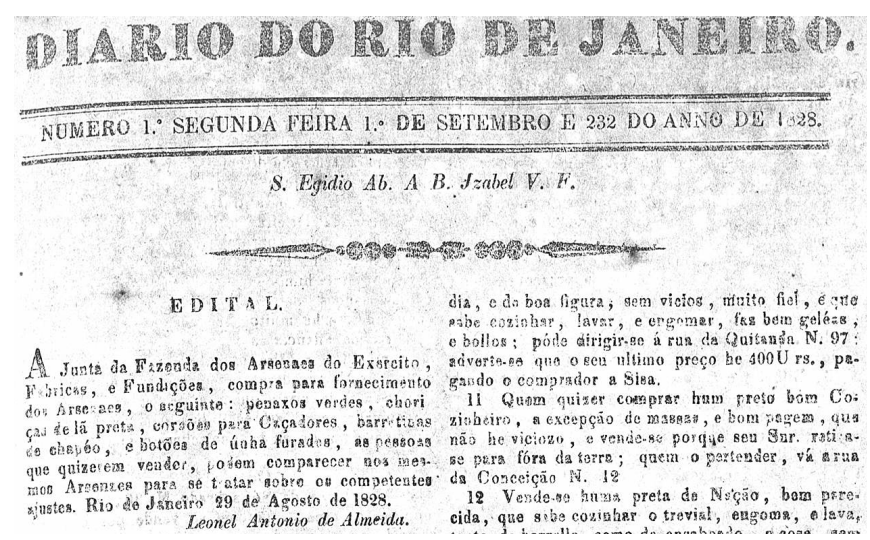

\title{
Espaço urbano pela narratividade dos anúncios de Jornal no Brasil oitocentista ${ }^{1}$
}

Urban space by the narrativity of newspaper ads in 19th century Brazil

\section{Vinícius Brito ${ }^{2}$ \\ ORCID: https://orcid.org/0000-0001-5567-6284}

\begin{abstract}
Resumo: Como a imprensa anunciava o espaço urbano no Brasil oitocentista? A partir da questão de pesquisa, analisa-se neste trabalho o discurso sobre espaço urbano brasileiro, especialmente no tocante à morada no século XIX. O objetivo geral do artigo é analisar anúncios pertinentes a essa temática no Diário do Rio de Janeiro $(D R J)$ e os objetivos específicos são verificar textos da imprensa dos oitocentos frente à História do Jornalismo e analisar a narratividade mesma dos anúncios em circulação. Filiando-se teórica e analiticamente à Análise do Discurso, a investigação reúne textos das seções de venda e aluguel de moradas no $D R J$ de 1821 a 1831, sendo a consulta feita pela Hemeroteca Digital da Biblioteca Nacional. Nos anúncios analisados, há uma relação parafrástica entre casa e propriedade, efeito do pré-construído no discurso autorizado pela narratividade dos jornais.
\end{abstract}

Palavras-chave: Análise do Discurso; História do Jornalismo; Espaço urbano; Narratividade; Anúncios de Jornal; Século XIX.

Abstract: How did the press announce urban space in nineteenth-century Brazil? From the research question, this paper analyzes the discourse on Brazilian urban space, especially regarding the address in the nineteenth century. The general objective of the article is to analyze pertinent ads to this theme in the Diary of Rio de Janeiro $(D R J)$ and the specific objectives are to verify texts of the press of the eight hundred against the History of Journalism and to analyze the same narrativity of the ads in circulation. Theoretically and analytically affiliated with Discourse Analysis, the research brings together texts from the sale and rental sections of the $D R J$ from 1821 to 1831, and the consultation was made by the Digital Library of the National Library. In the ads analyzed, there is a paraphrastic relationship between home and property, the effect of the prebuilt discourse authorized by the narrative of newspapers.

Keywords: Discourse Analysis; History of Journalism; Urban space; Narrativity; Newspaper advertisements; XIX century.

\footnotetext{
${ }^{1}$ Trabalho desenvolvido em estágio de pesquisa, sob supervisão do Prof. Dr. Rafael González Galiana, na Facultad de Comunicación da Universidad de Sevilla, via seleção e apoio institucional da Associação Universitária Iberoamericana de Pós-graduação, além de apoio financeiro da Coordenação de Aperfeiçoamento de Pessoal de Nível Superior (CAPES) desde o Brasil.

${ }^{2}$ Doutorando em Linguística pela Universidade Estadual de Campinas. E-mail: viniciusdebrito@gmail.com.
} 


\section{Primeiros versos}

Não te esqueças de mim, meu verso insano,

Meu verso solitário,

Minha terra, meu céu, meu vasto oceano,

Meu templo, meu sacrário.

(...)

Esquecimento! eclipse de horas mortas,

Relógio mudo, incerto,

Casa vazia... de cerradas portas,

Grande vácuo, deserto.

Esquecimento - Cruz e Sousa (2008, p. 452).

O corpo do sujeito se ata ao da cidade. O destino do sujeito capitalista coincide, dessa forma e por meio do fato linguístico, com o espaço urbano. O sujeito e a cidade se marcam no/pelo traço do discurso, apesar de silenciamento e esquecimento produzirem certos traços in-certos, dizerem versos (in)sanos e fazerem calar outros. eclipse, luzsombra em paradoxo constitutivo. Algo que cala no dito, algo que silencia na fala mesma, para "fazer sentido". Mas o traço se inscreve, clama: - não te esqueças de mim. O vasto oceano da história/historiografia pode produzir, igualmente, silenciamento, por alçar determinadas versões de um passado deserto (decerto?). Por outro lado, se vemos que o discurso está impregnado por exterioridade, em condições de produção que não se fixam (Relógio mudo) e nos significam, o discurso do século XIX, sobretudo aquele que versa o espaço urbano, surge potente, a dizer Minha terra, meu céu, meu vasto oceano. Nesse ponto, Cruz e Sousa, poeta negro e brasileiro nascido naquele século, vive. E “abrem-se portas" para formulações sobre nossa casa/morada, pujantes em um período de instabilidade política-social-econômica-tecnológica e constituição do espaço urbano do Brasil. Se o esquecimento está para a casa de cerradas portas, a materialidade discursiva deve permitir, em contramão, adentrar a essas paredes da moradia brasileira oitocentista, pela possibilidade mesma do texto, do verso, apontando sentidos à deriva.

Mergulhado no meu/dele verso, em letras de ciência (nunca neutra, senão atravessada pelo corpo investigador), me pergunto agora como a imprensa anunciava o espaço urbano no Brasil oitocentista? A questão atravessa esta pesquisa, com a qual pretendo analisar o discurso sobre morada e organização do espaço urbano brasileiro no século XIX, época em que a imprensa se alastrou no país. Para isso, o objetivo geral do artigo é analisar anúncios pertinentes à temática no Diário do Rio de Janeiro (1821-1858). Além do discurso sobre morada, os objetivos específicos devem dar conta, ainda, de (a) verificar textos da imprensa imperial frente à (cientifização de) História do Jornalismo; e 
(b) observar a narratividade — memória discursiva que institucionaliza/autoriza dizeres possíveis na imprensa, segundo Mariani (1997) - dos anúncios oitocentistas, descrevendo-os e interpretando-os.

Ao evocar espaço urbano, segundo Orlandi (2001, 2004, 2019), é preciso colocar a cidade como "pano de fundo" (ORLANDI, 2004, p. 11), pois a organização citadina, enquanto efeito do processo disciplinar urbanístico, marca a formulação do discurso pelo sujeito, produzindo sentidos que o significam na cidade e que tornam a cidade um sítio de significação na história. Assim, apesar de o Brasil apenas se tornar densamente urbano no século XX (MOLINA, 2015), o Rio de Janeiro foi uma exceção no período do Império (1822-1889) quanto ao crescimento populacional na cidade, o que justifica a escolha pela imprensa local - e não por outros jornais bem-sucedidos, como o Diário de Pernambuco, ainda em circulação no Brasil — nos oitocentos, século "de ouro" para a produção jornalística, segundo Traquina (2005), devido ao avanço do capitalismo, à democracia, à mudança social e ao surgimento de novas tecnologias ${ }^{3}$. Para se ter uma ideia, de 1821 a 1836, "apareceram na Corte nada menos de 297 periódicos" (MASCARENHAS, 1961, p. 9). A análise se debruça, ainda, sobre o discurso dos anúncios, porque vultosa receita dos jornais decorria de tal seção, especialmente para a venda/aluguel de escravos; Molina (2015) calcula em um milhão os anúncios dessa natureza em publicações fluminenses de 1808 a 1888.

Já os estudos sobre anúncio em jornais oitocentistas são vários, a exemplo de " $\mathrm{O}$ escravo nos anúncios de jornais brasileiros do século XIX”, de Gilberto Freyre, no qual o autor propõe uma Anunciologia. Em análise do discurso, igualmente, anúncios sobre escravos na imprensa do século XIX foram temas de trabalho de Brandão (2011) e Bastos e Medeiros (2007), por exemplo. Porém, o recorte que faço neste artigo, da narratividade do anúncio sobre espaço urbano, não figura na literatura em linguística e comunicação, salvo pesquisas em urbanismo (cf. ARAGÃO, 2008).

Dito isso, o corpus discursivo (ver Quadro 1), conjunto de sequências discursivas ${ }^{4}$ (Sds) em certas condições de produção de discurso (COURTINE, 2009), é composto por

\footnotetext{
${ }^{3}$ Para Sousa (2001), o surgimento da rotativa de Koning, em 1812, reduziu o valor da impressão de cópias e acelerou a institucionalização da imprensa no século XIX.

${ }^{4}$ Concordo com a crítica de Orlandi (1984) sobre a forma segmental, ainda muito ligada à fase distribucionalista, da noção de Sd em Courtine (2009), mas invisto nessa mesma noção porque J.-J. Courtine coloca o corpus diacrônico como possibilidade em análise do discurso, ainda que não o desenvolva ou não o amplie enquanto método.
} 
255 textos das seções de venda e aluguel - as quais geralmente ocupavam, em um total de 4-6 páginas, de duas até quatro laudas do jornal (ver Figura 1) — de casas/sobrados do Diário do Rio de Janeiro (DRJ) de 1821 a 1831. Nesse montante, o número de anúncios de aluguel (69\%) é consideravelmente superior aos de venda. Como verbal e não verbal se articulam na significação, também analisarei uma figura reproduzida da primeira edição do $D R J$. A consulta ao material se deu pela Hemeroteca Digital da Biblioteca Nacional do Brasil. Diante do volumoso arquivo e com o intuito de tornar o trabalho mais factível, elegi apenas a primeira edição de cada mês (de janeiro a dezembro) do $D R J$, a começar pelo fac-símile de $1^{\circ}$ de junho de 1821 , data em que o periódico começou a circular oficialmente na cidade. A justificativa para a delimitação temporal é compreender a produção jornalística sobre espaço urbano, em anúncios, no período préImpério e Império do Brasil.

\section{Quadro 1 - Corpus discursivo com anúncios de venda (V) e aluguel (A) no DRJ}

(1821-1831)

\begin{tabular}{|c|c|c|c|c|c|c|c|c|c|c|c|c|}
\hline & jan. & fev. & mar. & abr. & mai. & jun. & jul. & ago. & set. & out. & nov. & dez. \\
\hline 1821 & $*$ & * & $*$ & $*$ & * & $2 \mathrm{~V}$ & $1 \mathrm{~V}$ & $2 \mathrm{~V} 1 \mathrm{~A}$ & $1 \mathrm{~A}$ & 0 & $1 \mathrm{~V}$ & $1 \mathrm{~V} 3 \mathrm{~A}$ \\
\hline 1822 & $1 \mathrm{~V}$ & 0 & $2 \mathrm{~V}$ & $1 \mathrm{~A}$ & 0 & 0 & $1 \mathrm{~A}$ & $3 \mathrm{~A}$ & 0 & $1 \mathrm{~V}$ & $3 \mathrm{~A}$ & $1 \mathrm{~A}$ \\
\hline 1823 & $1 \mathrm{~V} 1 \mathrm{~A}$ & $2 \mathrm{~A}$ & $3 \mathrm{~V}$ & 0 & $1 \mathrm{~V} 1 \mathrm{~A}$ & 0 & 0 & $1 \mathrm{~V} 1 \mathrm{~A}$ & 0 & 1V1A & 0 & $1 \mathrm{~V} 2 \mathrm{~A}$ \\
\hline 1824 & $1 \mathrm{~A}$ & $1 \mathrm{~A}$ & $1 \mathrm{~A}$ & $2 \mathrm{~A}$ & $2 \mathrm{~V} 5 \mathrm{~A}$ & 1V1A & $2 \mathrm{~V}$ & $1 \mathrm{~V}$ & 0 & $1 \mathrm{~V} 3 \mathrm{~A}$ & 0 & $1 \mathrm{~A}$ \\
\hline 1825 & 0 & $1 \mathrm{~V}$ & $1 \mathrm{~A}$ & $2 \mathrm{~A}$ & $1 \mathrm{~V} 2 \mathrm{~A}$ & $1 \mathrm{~V} 1 \mathrm{~A}$ & 0 & $*$ & $1 \mathrm{~A}$ & $1 \mathrm{~V} 2 \mathrm{~A}$ & $3 \mathrm{~A}$ & $1 \mathrm{~V} 5 \mathrm{~A}$ \\
\hline 1826 & $1 \mathrm{~A}$ & $1 \mathrm{~V} 1 \mathrm{~A}$ & $1 \mathrm{~V} 1 \mathrm{~A}$ & 0 & $2 \mathrm{~V} 3 \mathrm{~A}$ & 1V1A & 0 & $1 \mathrm{~V} 2 \mathrm{~A}$ & $1 \mathrm{~V}$ & 0 & $1 \mathrm{~A}$ & $1 \mathrm{~A}$ \\
\hline 1827 & $1 \mathrm{~V}$ & 0 & $1 \mathrm{~A}$ & 0 & $1 \mathrm{~A}$ & $1 \mathrm{~A}$ & $2 \mathrm{~V} 1 \mathrm{~A}$ & $2 \mathrm{~A}$ & $1 \mathrm{~A}$ & $1 \mathrm{~A}$ & $1 \mathrm{~A}$ & 0 \\
\hline 1828 & $4 \mathrm{~A}$ & $1 \mathrm{~V} 2 \mathrm{~A}$ & $2 \mathrm{~V} 1 \mathrm{~A}$ & $1 \mathrm{~A}$ & $3 \mathrm{~V}$ & $1 \mathrm{~V} 3 \mathrm{~A}$ & 1V1A & $1 \mathrm{~V} 3 \mathrm{~A}$ & $1 \mathrm{~V} 1 \mathrm{~A}$ & $1 \mathrm{~A}$ & $3 \mathrm{~V} 1 \mathrm{~A}$ & $1 \mathrm{~A}$ \\
\hline 1829 & $1 \mathrm{~A}$ & $3 \mathrm{~A}$ & $1 \mathrm{~A}$ & $1 \mathrm{~V} 2 \mathrm{~A}$ & $2 \mathrm{~A}$ & 1V1A & $1 \mathrm{~V} 2 \mathrm{~A}$ & $2 \mathrm{~A}$ & $3 \mathrm{~A}$ & $1 \mathrm{~A}$ & $1 \mathrm{~A}$ & $1 \mathrm{~V} 2 \mathrm{~A}$ \\
\hline 1830 & 0 & $5 \mathrm{~A}$ & $2 \mathrm{~A}$ & $2 \mathrm{~A}$ & $1 \mathrm{~V} 3 \mathrm{~A}$ & $1 \mathrm{~A}$ & $1 \mathrm{~V}$ & $5 \mathrm{~A}$ & $1 \mathrm{~A}$ & $1 \mathrm{~A}$ & $2 \mathrm{~A}$ & $*$ \\
\hline 1831 & $3 \mathrm{~A}$ & $1 \mathrm{~V} 10 \mathrm{~A}$ & $2 \mathrm{~A}$ & $2 \mathrm{~V} 3 \mathrm{~A}$ & $3 \mathrm{~V} 5 \mathrm{~A}$ & $4 \mathrm{~A}$ & 1V1A & $3 \mathrm{~V} 2 \mathrm{~A}$ & $1 \mathrm{~V}$ & $2 \mathrm{~V} 4 \mathrm{~A}$ & $2 \mathrm{~V} 5 \mathrm{~A}$ & $4 \mathrm{~V} 1 \mathrm{~A}$ \\
\hline
\end{tabular}

*Sem publicação do $D R J$ nesta data, segundo a Hemeroteca Digital.

Como pretendo analisar o discurso sobre espaço urbano neste trabalho, não considerei, para a constituição do corpus, anúncios de moradas semi-urbanas/rurais (fazendas, chácaras, situações, sítios etc.), com expressa distância geográfica em relação ao centro urbano do Rio de Janeiro. Dizendo de outro modo, a busca por material se 
deteve a anúncios de casas no $D R J$, desprezando demais itens comerciais ou empreendimentos (como casa de secos e molhados) sem relação com o lar. Nesse conjunto de textos pertinentes à questão de pesquisa, foram notadas algumas repetições (sobre a casa, o espaço urbano brasileiro) no fio do dizer, o que me levou às sequências discursivas. Pelo dispositivo teórico-analítico da Análise do Discurso (ORLANDI, 2009; PÊCHEUX, 1997a, 1997b), respondendo à questão de pesquisa, e em determinadas condições de produção do discurso, as sequências discursivas sequencializam elementos do saber, articulando a formulação (COURTINE, 2009, 2016). A transcrição dos textos seguirá, por sua vez, orientações do II Seminário para a História do Português Brasileiro (GUEDES, BERLINCK, 2000). Ainda que não mantenha o leiaute dos anúncios, buscarei preservar, com convenções de transcrição, marcas linguístico-discursivas nos/dos anúncios. Com numeração contínua, as $\mathrm{Sds}$ com trechos sublinhados correspondem ao gesto de análise e a parte destacada em itálico no corpo do artigo, aos anúncios.

Para uma leitura contemporânea de corpus em diacronia, uma das formas de constituição de corpora em AD, segundo Courtine (2009), parto do princípio de que há uma certa estabilidade de sentido na língua ao longo do tempo, devido às condições de produção, que não são fixas nem estáticas. Reconheço, porém, que a estabilidade se produz enquanto efeito para o sujeito, uma vez que os sentidos não são transparentes (PÊCHEUX, 1997a, 1997b) e que tal efeito ocorre também em corpus sincrônico, no qual o sentido sempre pode vir a ser outro, sempre pode derivar, pela historicidade, ainda que haja um efeito (ideológico) de estabilidade a apontar esse-ou-aquele sentido na/pela interpretação do sujeito-leitor. Assim, para o analista, diante de corpus/corpora em diacronia, instala-se uma contradição mesma do dispositivo teórico-analítico sobre o constitutivo efeito metafórico da língua, o que não nega, contudo, a possibilidade (jamais completamente estável e objetiva/positiva) de análise desse tipo de material, assumindose uma análise do discurso marcada necessariamente pelo tempo presente. Relógio mudo, incerto, ecoando Cruz e Sousa (2008), dos esquecimentos/descobrimentos.

\section{Folhas luso-brasileiras}

Em análise do discurso, as condições de produção estão na dimensão material, institucional e imaginária (ORLANDI, 2009). Por isso, as condições de produção não se constituem à parte do dizer, não são o reflexo de uma exterioridade e não formam um co(n)texto - destacável, separável —, mas se embrenham no texto. O discurso se tece 
na relação fora/dentro (ORLANDI, 1995) de uma exterioridade constitutiva para a inscrição do sujeito no e pelo discurso. Então, se existe um campo discursivo de referência que homogeneíza os materiais de análise, pelas condições de produção (COURTINE, 2009), investigar discursos sobre espaço urbano no século XIX demanda compreender a institucionalização do jornalismo na sociedade luso-brasileira imperial, porque, segundo Traquina (2005, p. 34), a imprensa e os jornalistas devem sua emergência, e, acrescento, sua simbolização, à industrialização e à urbanização naquele século.

No Brasil, a imprensa irrompe em uma complexa forma social. A imprensa noção que requer alguma transmissão de informação ${ }^{5}$, formulação regular para um público imaginado - se inscreve discursivamente e diz de uma sociedade proto/lusobrasileira do século XIX. Nossas folhas volantes devem sua constituição a uma certa tradição impressa ibérica e ao contato dos redatores da então Colônia com a imprensa internacional (MOREL, 2008). Ainda que haja registros da Gazeta de Lisboa no Rio de Janeiro desde 1778, a Impressão Régia (a tipografia real) passou a imprimir a Gazeta do Rio de Janeiro em 1808, seguindo padrão do Antigo Regime. A Gazeta do Rio era, em aspectos técnicos, semelhante à de Lisboa (BARBOSA, 2010; MOLINA, 2015).

Grosso modo, o início da atividade jornalística no Brasil foi marcado pela divulgação política, de acordo com Molina (2015), uma tradição da imprensa lusa, majoritariamente opinativa ou de partido, sendo o artigo de opinião o principal texto jornalístico à época (SOUSA, 2001). Porém, não são todos os jornais luso-brasileiros a publicar o debate político: o Jornal do Commercio e o Diário de Pernambuco, na década de 1820, por exemplo, destacavam notícias mercantis, segundo Morel (2008). A Gazeta do Rio também tinha uma ampla seção de anúncios, indicando que tais jornais funcionavam para divulgar diversos produtos e serviços em uma sociedade mercantil (MARTINS, 2008).

O Estado absolutista e a mercantilização do escravo se inscreviam nas páginas dos jornais e, depois do término da censura/Impressão Régia, em 1821, as instituições jornalísticas se proliferam no país (BARBOSA, 2010), devido à Revolução Constitucional, que estabeleceu liberdade de imprensa em Portugal em 1820 e depois se estendeu para além da Península. Nesse cenário, surge em tipografia particular o Diário do Rio de Janeiro, em 1821, "pela modica quantia de 640 réis mensalmente" (DIÁRIO..., 1821 , p. 1). Dito apolítico, o periódico era conhecido popularmente como "Diário do

\footnotetext{
${ }^{5}$ Fiando-se à análise do discurso, sabemos que o discurso é mais do que transmissão de informação, pois se dá pelos efeitos de sentidos (PÊCHEUX, 1997a, 1997b).
} 
Vintém", pelo baixo preço do exemplar, ou de "Diário da Manteiga", devido aos produtos anunciados. Diante da minoritária faixa de leitores brasileiros na segunda década de 1800 , cerca de 20\%, segundo projeção de Marchelli (2006), "a publicação teve boa acolhida; em seu segundo mês, já contava com mais de 800 subscritores, e a tiragem só não atingia a marca de 1000 exemplares" (CAMARGO, MORAES, 1993, p. 270).

Lado a lado, o $D R J$ seguia o estilo de gazetas nas quais circulavam avisos sobre as mais diversas mercadorias (BARBOSA, 2010). Em seu debute, as primeiras páginas reuniam informações meteorológicas, editais, comunicados, anúncios de venda, compra e aluguel, leilões e "notícias particulares". Na edição inaugural, destaquei o plano do redator Zeferino Vito de Meirelles, com carreira ascendente de operário a vice administrador da Impressão Régia, nas Sds:

Sd1: PLANO || Para o estabelecimento de hum util e curiozo DIARIO | nesta Cidade (DIÁRIO..., 1821a, p. 1, grifo do autor)

Sd2: Zeferino Vito de Meirelles convencido da utilidade, que ao | Publico resultará de hum Diario, no qual gratuitamente se impri- $\mid$ mão todos e quaesquer annuncios ou noticias particulares (que con- | venhão e seja licito imprimir) inclusive os dos Divertimentos e Ex- | pectaculos Publicos (...), tem tomado a si a penoza tarefa de publicar o referido Dia- | rio (...), exigindo-o assim a impor- | tancia dos Annuncios, que houverem a fazer-se, declarando desde | já que não haverá outra perferencia na publicação dos mesmos se | [ilegível]ão a que a razão e a sua natureza exigirem [...]. || Portanto roga encarecidamente a todas as pessoas (...) queirão ter a bon- $\mid$ dade de mandar entregar, ou deitar os seus annuncios e noticias na | respectiva Caixa (...), na certeza de | que serão inseridos com a maior prontidão possivel, e com toda a rasoavel imparcialidade (DIÁRIO..., 1821a, p. 1)

$\mathrm{Na} \mathrm{Sd} 1$, o redator propõe duas finalidades para o jornal, pelo funcionamento do Para enquanto conjunção subordinada final (subordinada à ideia do plano do Diário): que seja util e curiozo. O adjetivo util, que aparecera inicialmente, é retomado na $\mathrm{Sd} 2$ pelo nome utilidade na justificativa para o estabelecimento de tal periódico, desde que "convença" a Zeferino Vito de Meirelles, como figura que autoriza o trabalho jornalístico e os anúncios a serem impressos.

Mais adiante, explica-se que o objetivo das folhas são a publicação de todos $e$ quaesquer annuncios ou noticias particulares (que convenhão e seja licito imprimir), em que se associada universalidade (pelo quantificador todos) à imprensa e uma clara distinção, por meio da conjunção alternativa ou, entre annuncios e noticias particulares, significando-os pela oposição, apesar da formulada importancia dos Annuncios. Por outro lado, o advérbio "inclusive", em inclusive os [anúncios] dos Divertimentos e 
Expectaculos Publicos, associa manifestações culturais a esse tipo de publicação (não de notícias particulares, pelo pronome demonstrativo os), demonstrando, porém, que o cunho (narratividade) dos anúncios na imprensa não seria comumente os Divertimentos, senão produtos da sociedade mercantil.

Ainda nessa formulação, a memória de uma Imprensa Régia parece constituir o ofício jornalístico enquanto passível de regulação, cujo material seja licito imprimir, e de penoza tarefa. Ao final da $\mathrm{Sd} 2$, aparecem, também, dois nomes associados à imprensa, seja em a maior prontidão possivel, seja em toda a rasoavel imparcialidade. $\mathrm{O}$ sentido de rasoavel imparcialidade já aparecera - daí o processo de paráfrase, o já-dado sobre outra forma (ORLANDI, 1984) — pelo pronome indefinido em quaesquer annuncios... que convenhão, colocando ressalvas à proposta de publicar "todos os anúncios" e abrindo lastro na desejada imparcialidade de escolha dos anúncios (ou noticias particulares). A história do jornalismo no Brasil, e, especialmente, do $D R J$, impresso durante as duas primeiras décadas do século XIX, inaugura uma narratividade jornalística (que vise à imparcialidade, à prontidão, à utilidade, ainda que restrita a critérios do dono da empresa), que formula sobre guerras no Velho Mundo ao mesmo tempo que anuncia a formação do espaço urbano brasileiro.

\section{Anúncio e paradigma dicotômico}

A prática jornalística, como a conhecemos hoje, remonta aos oitocentos, com a expansão de uma atividade de trabalho cujo objetivo era "fornecer informação e não propaganda" (TRAQUINA, 2005, p. 34). No século XIX, o surgimento da penny press, movimento que inventa nos Estados Unidos a manchete de primeira página como estratégia comercial (BARSOTTI, 2015), consegue converter os jornais em um lucrativo negócio, abrindo espaço para a comercialização de um "novo" produto: as notícias 6 (TRAQUINA, 2005). Nessa visada, jornalismo se constitui enquanto exercício criativo restrito a fatores temporais, suporte físico e critérios hierárquicos, mas, sobretudo, se dá pela oposição à propaganda, como está textualizado em annuncios ou noticias particulares, na $\mathrm{Sd} 2$, e no trabalho de Nelson Traquina, que escreveu "Teorias do

\footnotetext{
${ }^{6}$ Concordo com Traquina (2005) quando afirma que notícia é produto criativo e rotineiro do jornalismo, mas sou crítico à noção de fato (naturalizante, transparente). A notícia aparece (ir)regular como um texto, uma versão decidida entre tantas possíveis por determinados valores culturalmente criados e reconhecidos, podendo se vincular a uma ou a várias formações discursivas (PÊCHEUX, 1997a, 1997b), e não se desprende das relações de forças que atravessam o trabalho do jornalista desde a estrutura técnica até a sugestão das pautas, passando pela hierarquização das informações até a circulação do discurso jornalístico nos diversos suportes.
} 
Jornalismo" (2005). Curiosamente, a afirmação de uma prática jornalística é formulada ora pela negação ora pela oposição à propaganda/anúncio, em jornais como o Diário do Rio de Janeiro, diacronicamente, e na produção teórica contemporânea sobre jornalismo. Efeitos de uma dicotomia.

O paradigma dicotômico jornalismo/propaganda é uma marca do pensamento de Nelson Traquina sobre história do jornalismo, negando a propaganda nesse processo institucional — para Pizarroso (1993, p. 29), por exemplo, propaganda comumente passa a ter um "caráter pejorativo" na sociedade ocidental, podendo significar o discurso propagandístico como "carente de honradez" —, rechaçando-a ou apagando-a da divulgação jornalística. Assim, ainda que Traquina relacione o financiamento dos anúncios à industrialização da (proto)imprensa, explica cientificamente a fundação do jornalismo por um modelo de oposição:

As novas formas de financiamento da imprensa, as receitas da publicidade e dos crescentes rendimentos das vendas dos jornais, permitiram a despolitização da imprensa, passo fundamental na instalação do novo paradigma do jornalismo: o jornalismo como informação e não como propaganda, isto é, um jornalismo que privilegia os fatos e não a opinião. Com as novas formas de financiamento, a imprensa conquista uma maior independência em relação aos partidos políticos, principal fonte de receita dos jornais ainda no início do século XIX. (TRAQUINA, 2005, p. 36, grifo meu)

Friso, porém, que Traquina (2005, p. 37) não nega o papel central da propaganda na sociedade capitalista e na empresa jornalística ao afirmar que, já ao final do século XIX, "os armazéns, em conjunto com os medicamentos, eram a base de sustento das colunas de publicidade nos jornais. Os pequenos anúncios ganharam importância”. Pontuo, em contramão ao que expõe o autor português e diante do corpus discursivo reunido neste trabalho, a importância dos anúncios, pela formulação do espaço urbano em uma pulsante e crescente sociedade mercantil, em cidades como o Rio de Janeiro, a príncipio dos 1800, para uma história do jornalismo que não atende a um paradigma, na linha Traquiniana. Uma proto-imprensa brasileira que, ainda que oponha jornalismo (fiando-se a uma memória da profissão enquanto imparcial; ver Sds 1 e 2) à propaganda, se formula pela narratividade mesma dos anúncios.

Por outro lado, o corpus discursivo composto por anúncios do $D R J$ - cuja seção antecedeu os atuais classificados, explica Molina (2015), uma vez que a imprensa transformou a troca de bens na cidade, substituindo o anúncio manuscrito das ruas — nas 
duas primeiras décadas do século XIX abre outros sentidos para produção de conhecimento sobre a imprensa oitocentista, dita "eminentemente" política/doutrinária (MOLINA, 2015); marcada pelo "privilégio dos textos opinativos e interpretativos, em que cada episódio ou acontecimento era expressamente relacionado a uma linha de pensamento determinada" (LAGE, 2001, p. 18); tida como via de excelência do artigo de opinião (SOUSA, 2001); e, por fim, comandada, em meados daquele século, "ora para um, ora para outro dos dois partidos alternadamente no Governo" (MASCARENHAS, 1961, p. 9).

Ainda que a análise dos autores de História do Jornalismo esteja marcada pelos corpora analisados - Molina, por exemplo, traz recortes da Gazeta do Rio de Janeiro e da Gazeta de Lisboa, com publicações de atos do governo e do exterior —, jornais como o $D R J$ nos mostram a associação inegável entre notícia e anúncio, antes mesmo do surgimento da penny press, pois, à época, a imprensa não utilizava "títulos gritantes" (MASCARENHAS, 1961, p. 283), o que não a impedia de publicar anúncios das mais diversas mercadorias. O discurso dos anúncios parece quebrar, portanto, uma dicotomia na produção científica sobre Jornalismo, atravessado pela divulgação (e não apenas o financiamento) de propaganda. A seção de anúncios é, no mínimo, “curiosa”, e não apenas responsável pela receita dos periódicos do início do século XIX, como expõe Mascarenhas (1961, p. 283):

Na seção de anúncios e de Apedidos, encontravam os grandes jornais a fonte de receitas substancial. Bem curiosa esta seção. As discussões das demandas jurídicas, com sabor de escândalo, transpunham-se para ela. Cobravam-se dívidas mediante comunicados onde o credor pedia o pagamento do débito sob ameaça de publicação do nome do devedor. Denúncias contra a administração, autoridades, direção de colégios, contra os políticos, os vizinhos, as desavenças pessoais, tudo sob o anônimo, achavam ali seu desaguadouro.

Discursos entrelaçados, pelo fio do dizer, bem como a produção mítica clássica, na qual Mercúrio nasce de Júpiter e Maia para anunciar a fala dos deuses ao mundo, tendo instrumentos como a flauta para aturdir de notícias homens e mulheres. Dotado de gênio eloquente, Mercúrio exercia, ao mesmo tempo, gosto pelas finanças, simbolizando um duplo mecanismo: enquanto anuncia o divino à terra, Mercúrio se compromete com o metal. Um corpo de asas e de tecnologia humana, comumente usado por jornais para retomar um papel social, funcionamento do imaginário na memória do dizer. 
Figura 1 - Fac-símile do $D R J$ a $1^{\circ}$ de setembro de 1828

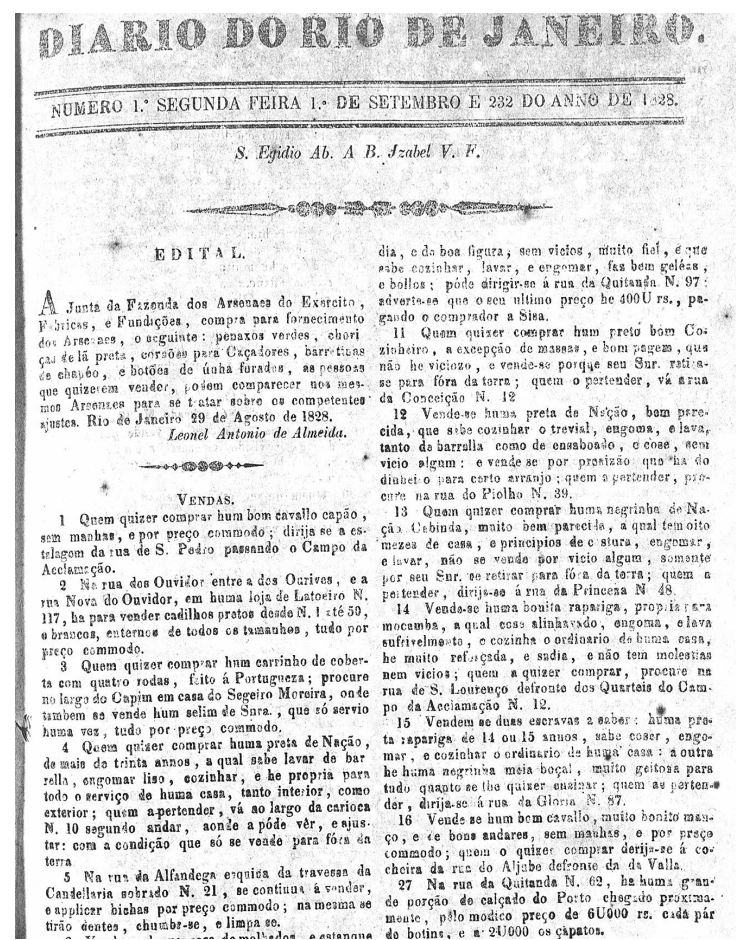

Fonte: Hemeroteca Digital da Biblioteca Nacional do Brasil

Figura 2 - Criatura acima da marca Diário do Rio de Janeiro na primeira edição do jornal

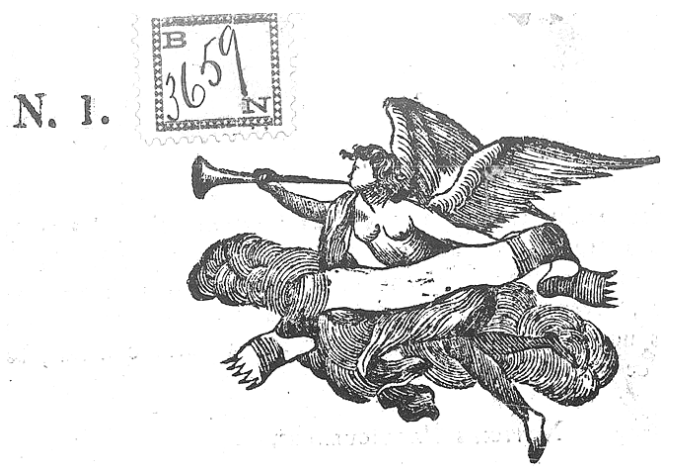

Fonte: Hemeroteca Digital da Biblioteca Nacional do Brasil

O Diário do Rio de Janeiro, pelas condições mesmas do discurso, imprime a imagem de Mercúrio (CAMARGO, MORAES, 1993) na sua edição inaugural, em 1821, com que começo a verificar os primeiros anos da imprensa brasileira e uma relação, constitutiva e inegável, diante das formulações analisadas, dessa prática profissional com os anúncios, o que convence porque, também na primeira geração de jornais lusobrasileiros, as seções opinativas e informativas (a exemplo de anúncios e notícias) estavam relacionadas, imbricadas (MOREL, 2008) pela e na narratividade jornalística. 


\section{Da narratividade anunciada}

Diante do corpus em diacronia no Quadro 1, noto dizeres possíveis que formulam sobre o espaço urbano luso-brasileiro, um elemento que está ao passo da memória discursiva - ou seja, a possibilidade de que "algo fala antes, em outro lugar, independentemente" (ORLANDI, 2008, p. 59) - e que institucionaliza um determinado modo de dizer (e não outros). O processo se constitui pela narratividade? , "um fio que tece e conduz nos jornais o ecoar das repetições parafrásticas, impedindo o deslizar dos significantes e /ou as resistências históricas, misturando passado, presente e futuro" (MARIANI, 1996, p. 107). Narratividade, nesse sentido, produz efeito de estabilidade em determinados textos, pela materialidade da língua e pela historicidade.

Ainda que a produção do discurso implique constituição (pela memória mesma do dizer em contexto histórico-ideológico), formulação (momento de atualização de memória na língua) e circulação, a narratividade funciona regulando os sentidos — daí, talvez, a separação estanque, formulada na primeira edição do $D R J$, entre anúncios e notícias particulares indicar para essa distinção na/pela história da imprensa. Desse modo, antes mesmo de folhear um jornal como o Diário, o sujeito-leitor tem para si um modo de encarar o periódico e suas seções, uma maneira de organizar os discursos sobre o espaço urbano, na percepção imediata das folhas volantes. O funcionamento da narratividade, com efeito, torna possível ao analista observar repetições no corpus de anúncios do século XIX.

Antes de seguir a análise, me valho do trabalho de Silva (2007) sobre regularidades discursivas nos/dos anúncios, entendendo-os como precursores dos atuais classificados em circulação na imprensa. No entanto, produzo algumas ressalvas em relação a essa pesquisa tipológica, uma vez que se filia à Linguística Textual e acredita que os textos de anúncios "constituem-se em um gênero, pelo fato de possuírem uma função sociocomunicativa" (SILVA, 2007, p. 214). Aqui, não movo a noção de gênero na análise dos anúncios, pois me interessa neste momento o funcionamento da narratividade na imprensa do século XIX, estabilizando determinados sentidos, pelas condições de produção do discurso, na seção de anúncios. Ao mesmo tempo, não me parece a língua, materializando o discurso, produzir uma função sociocomunicativa, de uma interação informativa tal e qual, diante do efeito metafórico e da possibilidade mesma de falha (PÊCHEUX, GADET, 2004) nessa imaginada transmissão de

\footnotetext{
${ }^{7}$ A noção de narratividade em Mariani (1996) guarda alguma distinção da que aparece em Orlandi (2017, p. 75), para quem, amplamente, narratividade é "funcionamento e modo de textualização da memória".
} 
informação. O que há, isto sim, são efeitos de sentido produzidos entre locutores (ORLANDI, 2007; PÊCHEUX, 1997a), pelo discurso sobre o espaço urbano.

Recorro, por outro lado, a Silva (2007) pela proposta de análise discursiva de anúncios de jornais, distinguindo-lhes as marcas linguísticas em Situação (localização espaço-temporal ou topológica); Qualidades (adjetivação sobre o espaço); e Elementos ou partes (descrição sobre elementos da morada). Não quero com tal gesto propor uma análise do texto em partes destacáveis (como se o texto não fosse uma unidade de análise), já que o penso na sua materialidade, na relação fora/dentro com as condições de produção; contudo, o método de Silva parece produtivo diante da escassez de trabalhos sobre o tema. Exponho, ainda, a noção de deixis discursiva em Maingueneau (1997), da formulação sobre o espaço-tempo manifesta no universo de sentido que uma formação discursiva constrói, para aprofundar a análise das Sds.

Sd3: Quem quizer comprar ou alugar, humas cazas por detraz| de Santa Anna, hindo para o Saco do Alferes, com 3 braças de frente, asobradadas para os fundos com 5 quartos em baixo e e[ilegível] | cima 6, e huma cavalharice, hum quintal com 55 braças de fun- | do com muitas larangeiras e varias fructas, e huma boa parreira | de bellas uvas: quem as pertender comprar ou alugar dirija-se á rua | do Sabão N. 96, que là achará com quem tratar; tem huma | porta no quintal, que tem sahida para o Mangue da Cidade Nova (DIÁRIO..., 1821b, pp. 2-3)

Sd4: Vende-se na rua de Santa Thereza, hu- $\mid$ ma caza de sobrado nova, ainda por acabar, com 5 janelas na frente; quem a quizer ver dirija-se a mesma rua N. 36 (DIÁRIO, 1821c, p. 2)

Sd5: Quem quizer alugar hum sobrado com com- | modos para familia; quem o pertender, dirija se a rua dos Pescadores casa N. 80, para o ver, e ajustar (DIÁRIO..., 1826, p. 3)

Inicialmente, e sabendo que verbal e não verbal significam, a narratividade dos anúncios do jornal se configura pela disposição gráfica desses textos, pelo leiaute que produzem, em diagramação de colunas — duas ou mais por página (ver Figura 1), a partir de edições do $D R J$ de dezembro de 1821. Os anúncios de venda, por sua vez, sempre precediam os comunicados oficiais (editais, registros do governo, atas etc.), sendo dispostos na lauda em numeração cardinal arábica crescente, tentativa de organização, pelo crivo do periódico, dos mais diversos textos sobre produtos e serviços na cidade.

Por outro lado, para além da deixis discursiva no cabeçalho do Diário (Rio de Janeiro, 1821, 1826 etc.), os anúncios constroem uma deixis topológica em por detraz de Santa Anna, hindo para o Saco do Alferes e sahida para o Mangue da Cidade Nova, na Sd3; na rua de Santa Thereza, mesma rua N. 36, na Sd4; e a rua dos Pescadores casa N. 80, na Sd5, por exemplo. A deixis discursiva tem a ver com a percepção mesma da cidade, 
traçando determinados itinerários, explorando determinados sentidos na organização citadina - ainda que dito discurso urbano venha a falhar diante da ordem da cidade, como escrevi alhures (BRITO, no prelo), a respeito do funcionamento de relativas com 'esquina' e 'rua' em jornais do século XIX. Construções como quem as pertender comprar ou alugar dirija-se á rua do Sabão N. 96, que là achará com quem tratar também formulam sobre o locutor, para que um possível locatário (quem as pertender) possa fazer negócio, uma vez convencido do anúncio.

A adjetivação parece compor, também, a descrição da casa no discurso dos anúncios de jornal do século XIX. Na $\mathrm{Sd} 3$, o processo se dá em 3 braças de frente, asobradadas para os fundos, muitas larangeiras e varias fructas, e huma boa parreira de bellas uvas, diferenciando a morada das demais e projetando-a imaginariamente para um possível locador. $\mathrm{Na} \mathrm{Sd4}$, igualmente, se tem o funcionamento do adjetivo, qualificando o bem em huma caza de sobrado nova. Voltando à proposta de Silva (2007), não saberia fazer muita distinção entre o passo da Qualidade e dos Elementos, uma vez que construções como com 3 braças de frente, asobradadas para os fundos com 5 quartos em baixo podem funcionar tanto descrevendo os cômodos/partes da casa, como adjetivando-os para dar alguma dimensão física da morada ao comprador. Fazer descrever o espaço urbano pela adjetivação.

Por fim, na passagem das Sds3-5, analiso construções (bastante regulares no dito corpus discursivo) com pronomes indefinidos e de indeterminação do locutor. $\mathrm{Na} \mathrm{Sd} 3$ e na $\mathrm{Sd}$, as formulações Quem quizer comprar ou alugar, humas cazas por detraz de Santa Anna e Quem quizer alugar hum sobrado com commodos para familia; quem o pertender têm um funcionamento indefinido ou generalizante devido ao pronome Quem, o qual amplia as possibilidades de venda dessas cazas por detraz de Santa Anna ou de tal sobrado com commodos para familia para possíveis locadores/compradores. Já na $\mathrm{Sd} 4$, o pronome pessoal clítico apassivante -se em Vende-se na rua de Santa Thereza huma caza de sobrado nova, apassiva e produz indeterminação sobre o locutor, enfatizando a ação de venda na formulação.

\section{Espaço urbano nos oitocentos}

Pelo batimento entre descrição e interpretação (sujeito analista), até o momento, apontei algumas regularidades, na materialidade mesma da língua, constitutivas do discurso sobre espaço urbano luso-brasileiro oitocentista, como dêixis discursiva situando a casa no espaço/tempo, determinando itinerários possíveis na cidade; descrição, 
geralmente adjetivada, de partes da casa (cômodos, sala, cozinha etc.); e construções com pronomes indefinidos/de indeterminação do locutor. No entanto, o discurso dos anúncios marca o urbano na língua, no deslize da organização urbanística a uma ordem mesma, um real da cidade.

A princípio dos oitocentos, a morada brasileira se distinguia no espaço (semi)urbano em edifício térreo (e suas partes, isto é, porta, janela, quarto, sala, etc.) e de sobrado, "de dois, três, quatro pavimentos, com loja, armazém ou depósito no térreo, escritório, salas, alcovas e cozinha nos andares superiores" (ARAGÃO, 2008, p. 151). Ao longo do século, o Rio de Janeiro, cuja população chegava a quase 300 mil moradores no Censo de 1872 (IBGE, s.a.), viu suas ruas serem calçadas, suas avenidas, iluminadas e seus passeios, criados. No entanto, nas três primeiras décadas dos 1800, o espaço urbano carioca, em especial, a rua, estava marcado pela "irregularidade do traçado, pela falta de alinhamento, pela ausência de calçamento, pela carência de iluminação pública e pela imundície" (ARAGÃO, 2008, p. 158).

Diante das formulações, em continuação, quero apontar para outros sentidos sobre morada/espaço urbano, em circulação no Diário à época, em determinada forma social, isto é, pela materialidade do discurso na língua, ver como funcionam os sentidos sobre morada nas sequências discursivas sobre o urbano oitocentista.

Sd6: Quem quizer comprar a propriedade de $\mid$ casas citas na rua da Moeda N. ${ }^{\circ}$ 24, dirija$\mathrm{se} \mid$ a casa contigua a mesma $\mathrm{N} .^{\circ} 25$, que lá acha- $\mid$ rà com quem tratar. (DIÁRIO..., 1822a, p. 2)

Sd7: Vendem-se 3 moradas de cazas na Villa | Real da Praia Grande, livres de Siza, e rendendo $\mid$ mensalmente $24 \$ 000$ réis por mez, quem as per- | tender dirija-se a botica do largo do Capim, do | Rocha, que ahi lhe dirão com quem hão de tratar | por quanto seu dono se auzenta desta terra. (DIÁRIO..., 1822b, p. 2)

Sd8: Vende-se huma morada de casas de so- | brado, livre de qualquer embaraço, na rua do | Piolho N. ${ }^{\circ} 108$; quem a quizer comprar, di- | rija-se as mesmas, para ver e ajustar com | sua dona. (DIÁRIO..., 1822a, p. 2)

Sd9: Quem quizer alugar hum sobrado, na rua $\mid$ de S. José, que serve para grande familia, tem | bons commodos, e hum bom sotão, com dois | quartos, e sala de vizita, e vista muito agrada- | vel para todos os lados; quem delle pertender, | vá na travessa de S. Francisco de Paula N. 29, | que achará com quem tratar: adverte se que he | pagando as bemfeitorias de tintas, que são 40U | réis, que o inquilino gastou. (DIÁRIO..., 1825a, p. 4)

Na Sd6, casas se relacionam à propriedade na construção Quem quizer comprar a propriedade de casas citas na rua da Moeda $N .^{\circ} 24$, na qual o nome propriedade "satura" o verbo transitivo comprar (algo), sendo casas (pelo funcionamento da 
preposição de) um complemento de tal nome, ou seja, a formulação poderia ser "Quem quizer comprar a propriedade cita na rua da Moeda N. ${ }^{\circ} 24$ ", em certo domínio semântico, mas não o é. Mantendo a mesma ideia, na $\mathrm{Sd} 7$, as moradas de cazas "rendem" mensalmente $24 \$ 000$ réis: "casa", aí, significando propriedade sobre a qual é possível ganhar dinheiro, réis. Já na $\mathrm{Sd}$, o sobrado (complemento preposicionado de morada de casas) é retomado, pelo pronome relativo que, como "útil”, já que serve para grande família, desde que pagando as bemfeitorias de tintas, que são $40 U$ réis, que o inquilino gastou. O sobrado, enquanto bem com o qual se lucra na cidade, também é o lugar da "benfeitoria", textualização sustentada discursivamente pelo liame entre casa e propriedade nessas condições de produção do discurso.

$\mathrm{Na} \mathrm{Sd} 7$, as 3 moradas de cazas na Villa Real estão livres de Siza (em construção restritiva, isolada com vírgulas, na qual há traços de concordância com moradas). O nome "siza"/"sisa", textualizado na formulação em maiúscula, se associa, segundo Bluteau (1728), a um tributo temporário sobre bens concedido à realeza. Igualmente, na $\mathrm{Sd} 8$, em huma morada de casas de sobrado, livre de qualquer embaraço, livre de qualquer embaraço - "embaraço" em Bluteau (1728, p. 468), vem dicionarizado como "impedimento, obstaculo, difficuldade" —, se produz uma restrição, pelo funcionamento das vírgulas, em relação a tal sobrado, o qual pode ser adquirido sem custos adicionais de impostos; ideia também sustentada pela relação casa-propriedade, posso argumentar. No entanto, as construções restritivas com livre(s) de Siza/de qualquer embaraço mostram, pelo contrário, a presença do Estado a regular a questão fundiária no Brasil imperial, pela cobrança de tributo (Real) àquele período: há moradas “embaraçosas”, em que deve se pagar Siza para ter direito ao espaço.

A relação discursiva entre casa e propriedade, pelo que analiso nas Sds6-9, sustenta o discurso sobre espaço urbano nos anúncios do $D R J$, pelo efeito mesmo de préconstruído. Tal relação parafrástica, de casa e propriedade ditas enquanto o "mesmo", está imbricada na narratividade jornalística, na inscrição do jornalismo em uma forma social capitalista, na circulação da seção de anúncios nos periódicos oitocentistas e na possibilidade de que, em tal seção, se anunciem propriedades para vender, comprar e alugar-se. Relação parafrástica estabilizada, pela repetição, funcionando pelo efeito de pré-construído, isto é, em elementos que se apresentam como se já estivessem dados no discurso (PÊCHEUX, 1997b). A casa é propriedade, rendendo quantia de réis por mez, do sujeito capitalista (aquele que é responsável/responsabilizado no/pelo jurídico), podendo o Estado re-cobrar tributos sobre tal bem. 
É interessante, ainda nas Sds7-8, o funcionamento de um sintagma nominal ao qual se associam os quantificadores 3 e huma, em moradas de cazas/morada de casas, uma vez que moradas/morada e cazas/casas surgem, pelo efeito de dicionarização, como o "mesmo" em dicionários da época (cf. PINTO, 1832; BLUTEAU, 1728). Bluteau (1728, p. 96), por exemplo, apresenta "morada" como nome feminino, "a casa, pousada, habitação ordinaria" - definição mesma de Pinto (1832). Já no verbete "casa", registra "edificio onde habita gente, morada, habitação", mas com deriva para "Peça, ou quarto do edificio v.g. ", casa de jantar, de dormir, de musica” (BLUTEAU, 1728, p. 241). A possibilidade de cazas/casas funcionar como "quarto do edifício" sustenta a textualização do sintagma nominal moradas de cazas/morada de casas, que também é regular, considerando os traços de concordância em número, nas Sds10-12.

Sd10: Quem quizer comprar huma morada de casa | no Areal de S. Gonçallo, ainda moderna, muito | bem construida (...), boa para | familia por ter muitos commodos; quem a perten- $\mid$ der dirija se ao becco de João Baptista casa N. 18, | que lá achará com quem tratar do seu ajuste (DIÁRIO..., 1828a, p. 1)

Sd11: Em humas das melhores ruas | desta Cidade, ha para se alugar hum | bom sotão com grande cozinha, duas | sallas, grande alcova, e tudo com mui- $\mid$ ta claridade, pois dezeja-se alugar a | pessoa capaz, e de muito pouca fami- | lia; quem o pertender póde procurar na rua do Sabão n. [ilegível]94. (DIÁRIO..., 1830, p. 2).

Sd12: Preciza se alugar huma morada de casas $\mid$ em qualquer rua da Cidade, sendo da rua dos $\mid$ Ourives para cima, que tenha loja e primeiro | andar, ou que tenha primeiro e segundo andar, | inda que este seja mais estreito que o primeiro, | devendo notar se que a casa tenha quintal; quem | tiver e quizer alugar procure ao escrivão do Civel da Corte Francisco Luiz da Silva, no be- | co do Piolho N. 18, ou annuncie neste Diario (DIÁRIO..., 1825a, p. 4). Sd13: Quem tiver e queira alugar algum sobra- $\mid$ dinho para pequena familia, porém que tenha | cocheira, e cavallariça para dous ou trez ani- | maes; ou ainda mesmo alguma casa terrea com | quintal, e corredor separado, e tenha portão | por onde possa entrar huma sege, seja no $\mid$ centro da Cidade, ou pelos sitios de Matta | Cavallos, rua do Lavradio, Cidade Nova, | Lapa do Desterro \&c., não excedendo o alu- $\mid$ guer mensal de 12:000 a 16:000 rs.; annuncie | por este Diario para serem vistas, e tratar-se do ajuste (DIÁRIO..., 1826, p. 3).

Sd14: Quem tiver para alugar hum sobrado, | (ainda que pequeno) ou casa terrea; porém que | tenha cocheira, ou armazem, sendo nas ruas | do Lavradio, dos Invallidos, e nas de mais | que precedem a estas; póde dirirgir-se á rua de | Santa Luzia N. 45, ou noticiar por este Dia- | rio, para ser procurado (DIÁRIO..., 1825b, p. 2).

Além da repetição do sintagma nominal morada de casas nas Sds 10 e 12, nas quais vem sempre precedido por quantificador (huma), a Sd10 adjetiva esse sintagma como ainda moderna, pois é preciso que a propriedade (aqui pelo efeito de préconstruído), por ter valor inerente, esteja nova — nesta época, moderna significava, pela dicionarização, o novo, o recente, e não um período temporal (BLUTEAU, 1728; PINTO, 
1832). Por outro lado, a mesma Sd investe em construções como muito bem construida, funcionando pelo pronome indefinido muito para realçar (a morada de casas não foi "apenas bem construida") determinadas partes da casa. A narratividade mesma dos anúncios, com os quais é preciso vender/alugar, em um processo de $\operatorname{argumentação~}{ }^{8}$ sobre a casa (função autor/efeito-leitor). $\mathrm{Na} \mathrm{Sd} 11$, a construção Em humas das melhores ruas desta Cidade, por sua vez, inscreve uma distinção, reproduzida pela organização urbanística, pois para haver ruas melhores na cidade é preciso que hajas as "piores". Classificação, no comparativo de superioridade, pelo adjetivo melhores. Em humas das melhores ruas, apesar do efeito generalizante, se valora (pela adjetivação) o bom sotão com grande cozinha, que deve ser "alugado apenas" a pessoa capaz.

$\mathrm{Na} \mathrm{Sd12}$, destaco a formulação Preciza se alugar huma morada de casas em qualquer rua da Cidade, sendo da rua dos Ourives para cima, pelo funcionamento do pronome indefinido qualquer e do gerúndio na oração subordinada (oração reduzida de gerúndio) em sendo da rua dos Ourives para cima; enquanto o "alugar morada em qualquer rua da Cidade" amplia as possibilidades de locação (sem distinção por bairro, freguesia etc.), a oração subordinada restringe a oração coordenada (Preciza se alugar... Cidade) e o sentido mesmo de Cidade ("apenas da rua dos Ourives para cima”). A expressão para cima também é bastante significativa, aqui, uma vez que uma marca de cidades fundadas por portugueses é a ligação entre a cidade alta (para edifícios administrativos e clericais) e a baixa (edifícios de serviço e de menor prestígio social), segundo Teixeira e Valla (1999). A cidade para cima significa diante do "outro" urbano, a cidade "da rua dos Ourives para baixo".

A Sd13 também localiza, pela deixis discursiva topográfica, a cidade, mas aquela em que não se possa gastar mais do que 16:000 rs por aluguel/mês. A restrição financeira que impõe o locatário ao possível locador se marca no espaço urbano, pelas conjunções coordenativas alternativas/disjuntivas seja...ou em seja [o sobradinho] no centro da Cidade, ou pelos sitios de Matta Cavallos, rua do Lavradio, Cidade Nova, Lapa do Desterro. A morada sempre significando, nessas condições de produção do discurso, como propriedade; e os sentidos de propriedade se espacializam na cidade, determinando ruas, determinando casas (pelo diminutivo sobradinho).

\footnotetext{
${ }^{8}$ Em Orlandi (2008), a argumentação funciona como mecanismo de antecipação, já que permite ao sujeito experimentar o lugar de um "outro" que o escuta; argumentação, nesse gesto teórico-analítico, está alinhada à função-autor e produzindo, indissociavelmente, um efeito-leitor no discurso.
} 
A textualização de sobradinho, inclusive, diz de uma memória urbanística, pois, no Rio de Janeiro, as casas térreas eram habitadas por populares enquanto o sobrado, por proprietários ricos (ARAGÃO, 2008). Na mesma Sd, o locutor clama pelo sobradinho, ou ainda mesmo alguma casa terrea com quintal. O "sobrado", para se textualizar nesta formulação, tem quer funcionar pelo diminutivo e ser comparado (ou) à casa terrea; não é necessário dizer "casinha térrea", pela relação material dela com sujeitos moradores de menos prestígio social naquela época. Igualmente, na $\mathrm{Sd} 14$, a construção ainda que pequeno nos mostra um imaginário sobre o sobrado, entendido como "grande", senão a conjunção ainda que não estaria aí textualizada. Relações de força (o lugar construído para que seja possível a descrição/formulação do redator sobre o espaço) na cidade, inscritas na e pela língua.

Sd15: Na rua de Matta Cavallos n. 138, | aluga-se hum casa nobre com duas sa- | las, oito alcovas, duas copas, grande $\mid$ casa de jantar, cosinha, tudo no an- $\mid$ dar de cima, tendo em baixo cocheira, | cavallariça, quartos para criados, e $\mid$ casa de pretos, e outros commodos, | com chacara; quem a pertender diri- | ja-se a mesma. (DIÁRIO..., 1830, p. 2).

Sd16: Aluga-se huma casa com cocheira para sage, | e commodos sufficientes para huma familia; com co- | zinha, e casa para escravos, e cavallariça, tudo se- | parado da casa, com hum bom pôço de agua para | serventia da dita, tanque de lavar roupa, com sua | competente chacarinha, com varios arvoredos de fruc- | tas, e flores, toda plantada de capim; sita na rua da Pedreira da Gloria N. 69 (DIÁRIO..., 1826, p. 3).

A Sd15 não textualiza o "sobrado", mas adjetiva a casa como nobre (não se fala apenas em casa, senão pela relação com o complemento nobre) e descreve seus elementos/partes, com duas sa-las, oito alcovas, duas copas, grande casa de jantar, cosinha. Interessante o quantificador hum diante do nome feminino casa nobre, justamente pelo sobrado ser o modelo de casa com mais de um andar à época. As partes da casa, ademais, são retomadas pela restritiva tudo no andar de cima, uma vez que em baixo estão cocheira, cavallariça, quartos para criados, e casa de pretos, e outros commodos, com chacara, produzindo, essa última descrição sobre o espaço, quase uma indistinção (até mesmo pela repetição da conjunção aditiva $e$ ) entre os elementos da casa para animais e aqueles destinados a criados e pretos. Enquanto se formula a casa nobre pelas oito alcovas, os outros commodos - como quartos para criados e casa de pretos — não são precedidos de quantificador, por exemplo. A casa nobre, porém, não é aquela dos elementos do andar de cima, senão a que se divide (e divide sujeitos moradores) entre os andares de cima e os de baixo. A deixis discursiva topográfica em no andar de cima e 
em baixo espacializa os sentidos pela verticalização (cima/baixo) do espaço e na oposição casa nobre/sobrado.

Da mesma forma, na Sd16, há “duas” casas ditas, apesar de o anúncio tentar alugar apenas huma casa com cocheira para sage. Ainda que o quantificador huma aponte para uma casa (enquanto "morada"), a formulação também anuncia a casa para escravos como elemento dessa mesma "propriedade" - a casa, pelo efeito de dicionarização, como quarto, cômodo, naquele século. Está, aí, a relação do sujeito morador que tem família para ocupar um commodo e de outro sujeito morador, que ficará separado da casa. A construção tudo separado da casa, restringindo os elementos cozinha, e casa para escravos, e cavallariça, mostra uma contradição mesma desse discurso. Ao mesmo tempo que a morada a ser alugada compõe todos esses elementos/partes, há uma determinação histórica dos sentidos a opor esses elementos da casa, separando-os, pois existe a relação de forças espacializando sentidos na casa e no discurso sobre espaço urbano, nessas condições de produção.

\section{Palavras derradeiras}

O verso, o dis-curso marca o sujeito desde a cidade e, como sujeito e cidade estão produzindo sentido lado a lado, o discurso versa o espaço urbano. Na passagem do tempo, palavras podem ser esquecidas, caladas, negligenciadas pela historiografia. Há sempre "uma terra, um céu, um vasto oceano" que se calam diante de um discurso conhecido, exaltado, autorizado, institucionalizado por uma narratividade, o que implica, por outro lado, a importância de voltar a ler arquivos diacrônicos, para mirar o passado constitutivo para a nossa interpretação contemporânea, para nossos gestos de análise atuais. $\mathrm{O}$ passado, assim, não surge como um relógio mudo, na expressão poética de Cruz e Sousa (2008), irrompe, isto sim, na historicidade pela qual se tece o discurso sobre espaço urbano. Propondo a cidade enquanto sítio de significação na história, me questionei neste artigo sobre formulações da urbe brasileira oitocentista, por meio de anúncios de venda e aluguel de morada no Diário do Rio de Janeiro.

O $D R J$ foi o primeiro jornal impresso em tipologia privada na nação e se produz em determinadas condições de produção, em um Estado absolutista e mercantil que experimentava os primeiros anos de liberdade de imprensa. Apesar da alta taxa de analfabetismo, o periódico era vendido a preço de "manteiga", com cerca de mil exemplares em circulação na segunda década do século XIX. Em um primeiro momento, analisei a dita distinção entre anúncio e notícias, formulada pelo primeiro plano do Diário 
e institucionaliza pela História do Jornalismo. Diante do corpus discursivo, propus que o material não funcionava dicotomicamente (pelo paradigma que tende a opor notícia a anúncio), abrindo uma nova mirada sobre os primeiros "noticiários" nacionais, na formulação indistinta de anúncios sobre os mais diversos produtos/serviços do Brasil (pré-)Império. Os anúncios estampavam mais da metade das folhas do $D R J$ e textualizavam, simbolizavam o espaço urbano dos oitocentos, em suas con(tra)dições.

Ressaltei, em segundo momento, a narratividade mesma dos anúncios de jornal no Brasil oitocentista, estabilizando determinadas séries parafrásticas (Figura 3), determinados modos de dizer, na relação função autor/efeito-leitor (argumentação). Pela narratividade de tais anúncios, verifiquei funcionamento da deixis discursiva topográfica (traçando determinados itinerários, explorando determinados sentidos na organização citadina) e de construções adjetivas sobre espaço e elementos da morada. Ademais, os anúncios de venda e aluguel de morada no Diário, os quais precediam comunicados oficiais a partir da primeira lauda, sempre textualizavam construções com pronomes indefinidos (ver Sd3, Sds 5-6 etc.) e de indeterminação do locutor (ver Sd4, Sds 7-8 etc.), pelo pronome pessoal clítico. A essa parte da análise, não quis chamar tipológica porque penso que as marcas apontadas são regulares dentro de determinado gesto de análise, pelas sequências discursivas apresentadas, em condições de produção do discurso não completamente estáveis nem fixas. As marcas analisadas apontam, porém, para traços distintivos do discurso dos anúncios, de acordo com os objetivos e a questão de pesquisa apresentados aqui. 
Figura 3 - Funcionamentos do discurso sobre espaço urbano em anúncios do século XIX

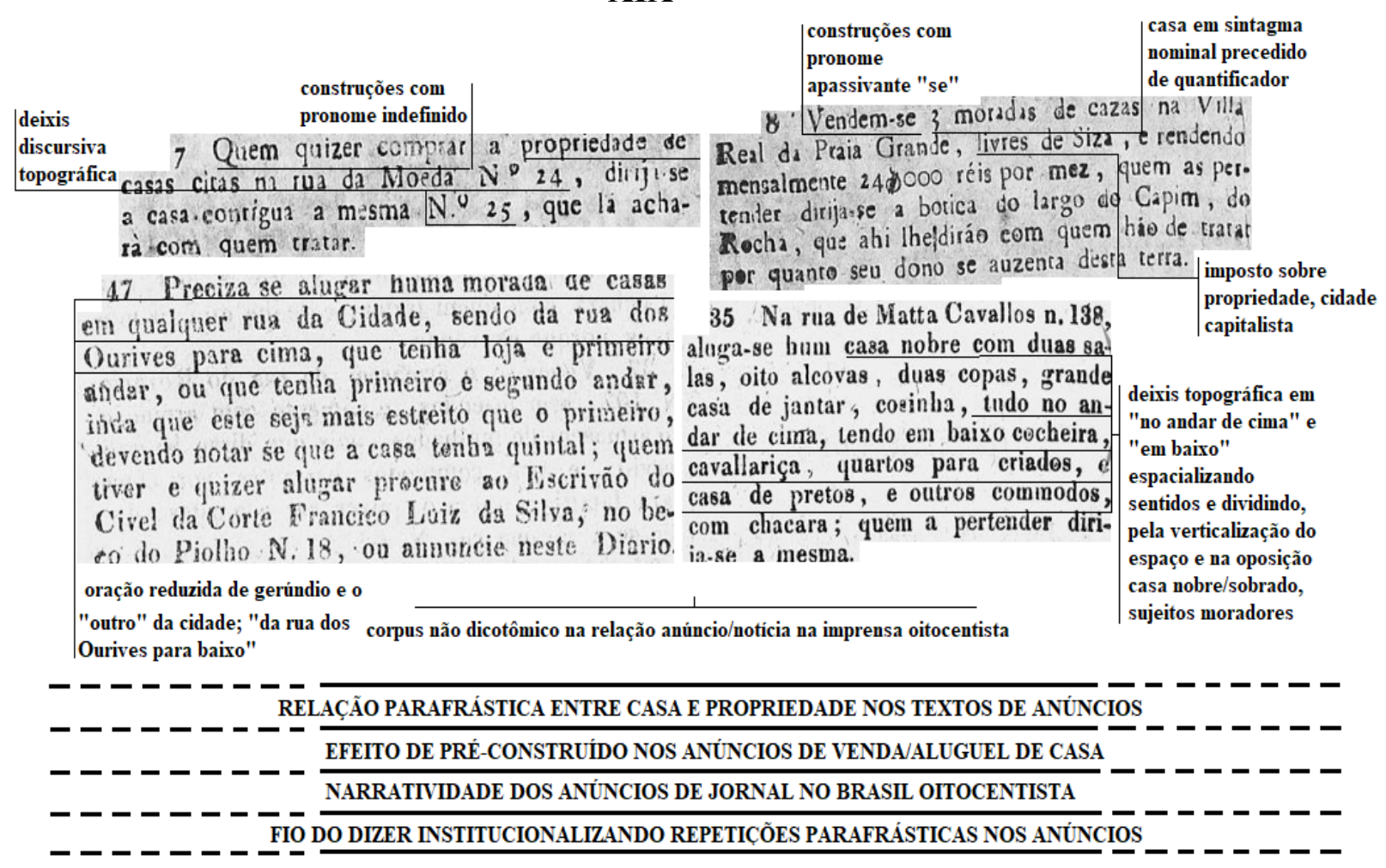

Fonte: Vinícius Brito (2019)

Pelo gesto de análise, também analisei que casa e propriedade funcionam como o "mesmo", enquanto efeito do pré-construído, nos anúncios de jornal nas primeiras décadas do século XIX. A relação parafrástica (ver Sds 6-9) sustenta o discurso sobre espaço urbano nos anúncios de venda e aluguel do $D R J$ e está imbricada na narratividade jornalística, pela seção de anúncios que assume (e estabiliza/institucionaliza na repetição) a morada enquanto propriedade que se vende/aluga. A textualização de siza $(\operatorname{Sd} 7)$, tributo temporário sobre bens pago ao Império, e embaraço (Sd8), por outro lado, dizem da presença do Estado na questão fiduciária brasileira oitocentista. A casa enquanto bem privado do sujeito capitalista sobre a qual tem poder de regulação o Estado, por meio do seu aparato jurídico.

As Sds dizem, ainda, da cidade e do seu "outro" constitutivo. Pelo funcionamento do pronome indefinido qualquer e da oração reduzida de gerúndio na $\mathrm{Sd} 12$, por exemplo, em Preciza se alugar huma morada de casas em qualquer rua da Cidade, sendo da rua dos Ourives para cima, temos na oração subordinada um sentido para cidade ("apenas da rua dos Ourives para cima"). A "cidade para cima" significa diante do "outro" urbano, a cidade "da rua dos Ourives para baixo". A Sd13 também localiza, pela deixis discursiva topográfica, a cidade, mas aquela onde não se possa gastar mais que 16:000 rs de aluguel 
por mês (efeito de pré-construído da casa enquanto propriedade). Restrição financeira marcada no espaço urbano. Sentidos de casa/propriedade espacializando-se em determinadas ruas e casas.

Já na Sd15 descreve as partes da casa pela restritiva tudo no andar de cima, opondo o andar de cima ao de baixo, onde estavam cavallariça, quartos para criados, $e$ casa de pretos, e outros commodos, com chacara. Descrição da casa nobre como a que divide não apenas elementos, mas sujeitos moradores entre os andares, pela deixis discursiva topográfica no andar de cima e em baixo, verticalização do espaço na oposição casa nobre/sobrado. Por fim, há na Sd16 a relação de sujeitos moradores distintos, uma vez que alguns têm família pode ocupar os cômodos da casa e outros devem ficar à parte (tudo separado da casa), separados da casa "principal". A determinação histórica dos sentidos opõe, nesta formação discursiva, em corpus histórico, os elementos da casa (listados nos anúncios pela descrição linguística).

Termino (texto-lauda: efeito de sentido) esta exposição com versos da música Oração, da cantora Linn da Quebrada (2019) — "meu-templo-meu-sacrário" —, que vem inscrever o "outro" da cidade (sem nação), pela resistência enunciada frente ao Esquecimento (sobre o que poetizava Cruz e Sousa, não causalmente) urbanístico, de cerradas portas cá-acolá, frente a (in-)certos sujeitos moradores (mulheres travestis negras) no espaço urbano. Memória que sustenta o dito (e o silêncio), memória na prática discursiva, pelo fato de que há língua-em-nós, para que se possa viver nelas e através delas. Cidade-sítio de significação espacializando sentidos, pelas relações de força na forma social capitalista. Enfim (?), por uma análise do discurso de corpus diacrônico e por uma análise contemporânea de tais versos, que tanto nos podem dizer hoje da nossa terra passada-presente(ficada).

Eu determino que termine aqui e agora $\mathrm{Eu}$ determino que termine em mim Mas não acabe comigo Determino que termine em nós e desate E que amanhã, que amanhã possa ser diferente com elas Que tenham outros problemas e encontrem novas soluções

E que eu possa viver nelas Através delas Em suas memórias (...) Entre a oração e a ereção Ora são, ora não são Unção, benção, sem nação Mesmo que não nasçam Mas vivem e vivem e vem Oração - Linn da Quebrada (2019, grifo meu) 


\section{REFERÊNCIAS}

ARAGÃO, S. A casa, o jardim e a rua no Brasil do século XIX. In: Em Tempo de Histórias. Programa de Pós-Graduação em História PPG-HIS/UnB, n. 12, Brasília, 2008.

BARBOSA, Marialva. História cultural da imprensa: Brasil, 1800-1900. Rio de Janeiro: Mauad X, 2010. Disponível em: www.encurtador.com.br/djlJ0. Acesso em: 11 set 2019.

BASTOS, Ana Karine Pereira de Holanda; CARVALHO, Nelly Medeiros de. O léxico dos anúncios de escravos nos jornais do Recife do século XIX (1853-1855). Dissertação (Mestrado). Programa de Pós-Graduação em Letras, Universidade Federal de Pernambuco, Recife, 2007.

BLUTEAU, Raphael. Vocabulario portuguez \& latino: aulico, anatomico, architectonico ... Coimbra: Collegio das Artes da Companhia de Jesu, 1728. 8 v., p. 433.

BRANDÃO, Helena Nagamine. Les esclaves dans les petites annonces des journaux brésiliens au dix-neuvième siècle : discours et idéologie. Argumentation et Analyse du Discours, 7, 2011. Disponível em: http://journals.openedition.org/aad/1230. Acesso em: 04 nov. 2019.

BRITO, Vinícius. Esquinas da/na língua: discurso urbano em jornais do século XIX. IX SEAD, Recife, 2019. No prelo.

CAMARGO, Ana Maria de Almeida; MORAES, Rubens Borba de. Bibliografia da Impressão Régia do Rio de Janeiro. São Paulo: Editora da Universidade de São Paulo/Kosmos, 1993.

COURTINE, Jean-Jacques. Análise do discurso político: o discurso comunista endereçado aos cristãos. São Carlos: EdUFSCar, 2009.

COURTINE, Jean-Jacques. Definição de orientações teóricas e construção de procedimentos em Análise do Discurso. Tradução de Flávia Clemente de Souza e Márcio Lázaro Almeida da Silva. Policromias, junho de 2016.

DIÁRIO do Rio de Janeiro, Rio de Janeiro, ed. 0600001, 1821a, p. 1.

DIÁRIO do Rio de Janeiro. Rio de Janeiro, ed. A1100001, 1821b, pp. 2-3.

DIÁRIO do Rio de Janeiro. Rio de Janeiro, ed. 1200001, 1821c, p. 2.

DIÁRIO do Rio de Janeiro. Rio de Janeiro, ed. 0300001, 1822a, p. 2.

DIÁRIO do Rio de Janeiro. Rio de Janeiro, ed. 0100001, 1822b, p. 2.

DIÁRIO do Rio de Janeiro. Rio de Janeiro, ed. 1200001, 1825a, p. 4.

DIÁRIO do Rio de Janeiro. Rio de Janeiro. ed. 0500001, 1825b, p. 2.

DIÁRIO do Rio de Janeiro. Rio de Janeiro, ed. 0300001, 1826, p. 3.

DIÁRIO do Rio de Janeiro. Rio de Janeiro, ed. 0600001, 1828a, p. 1.

DIÁRIO do Rio de Janeiro. Rio de Janeiro, ed. 0800001, 1830, p. 2.

FREYRE, Gilberto. O escravos nos anúncios de jornais brasileiros do século XIX. São Paulo: Ed. Nacional/Instituto Joaquim Nabuco de Pesquisas Sociais (Brasiliana), 1979.

GUEDES, Marymarcia; BERLINCK, Rosane de Andrade (Orgs.). E os preços eram commodos...: Anúncios de Jornais Brasileiros Século XIX. São Paulo: Humanitas/FFLCH/USP, 2000. 
IBGE. Sinopse do Censo Demográfico 2010 Brasil. Disponível em: www.censo2010.ibge.gov.br/sinopse/index.php?dados $=6 \& u f=00$. Acesso em: 22 nov. 2019.

LAGE, Nilson. Ideologia e técnica da notícia. $3^{\mathrm{a}}$ ed. - Ufsc-Insular, 2001.

MAINGUENEAU, Dominique. Novas tendências em análise do discurso. Tradução de Freda Indursky. Campinas: Pontes/Editora da Universidade Estadual de Campinas, 3a edição, 1997.

MARCHELLI, Paulo Sergio. As minorias alfabetizadas no final do período colonial e sua transição para o império: um estudo sobre a história social e educação no Brasil. Educação Unisinos, ed. 10, setembro/dezembro, 2006.

MARIANI, Bethania Sampaio Correa. O comunismo imaginário: práticas discursivas da imprensa sobre o PCB (1922-1989). 1996. 256f. Tese (doutorado) - Universidade Estadual de Campinas, Instituto de Estudos da Linguagem, Campinas, SP. Disponível em: http://www.repositorio.unicamp.br/handle/REPOSIP/270690. Acesso em: 06 nov. 2019.

MARTINS, Ana Luiza. Imprensa em tempos de Império. In: MARTINS, Ana Luiza; DE LUCA, Tania Regina (Orgs.). História da imprensa no Brasil. São Paulo: Editora Contexto, 2008.

MASCARENHAS, Nelson Lage. Um jornalista do império (Firmino Rodrigues Silva). São Paulo: Companhia Editora Nacional, 1961. Disponível em: https://bdor.sibi.ufrj.br/bitstream/doc/357/1/309\%20PDF\%20-\%20OCR\%20-

\%20RED.pdf. Acesso em: 18 nov. 2019.

MOLINA, Matías M. História dos jornais no Brasil: Da era colonial à Regência (15001840), 1a ed, São Paulo: Companhia das Letras, 2015.

MOREL, Marco. Os primeiros passos da palavra impressa. In: MARTINS, Ana Luiza; DE LUCA, Tania Regina (Orgs.). História da imprensa no Brasil. São Paulo: Editora Contexto, 2008.

ORLANDI, Eni Puccinelli. Análise de Discurso: Princípios e procedimentos. 8. ed. Campinas: Pontes, 2009.

ORLANDI, Eni P. (org.). Cidade atravessada: os sentidos públicos no espaço urbano. Campinas: Pontes, 2001.

ORLANDI, Eni Puccinelli. Cidade dos sentidos. Campinas: Pontes Editores, 2004.

ORLANDI, Eni Puccinelli. Discurso e Texto: formulação e circulação dos sentidos. Campinas: Pontes Editora, 2008.

ORLANDI, Eni Puccinelli. Efeitos do verbal sobre o não verbal. Rua, Campinas, 1:3547, 1995.

ORLANDI, Eni Puccinelli. Eu, Tu, Ele: Discurso e real da história. Campinas: Pontes Editores, 2017.

ORLANDI, Eni Puccinelli. O que é linguística. São Paulo: Brasiliense, 2007.

ORLANDI, Eni Puccinelli. Segmentar ou recortar? In: Linguística: Questões e Controvérsias. Uberaba: Curso de Letras do Centro de Ciências Humanas e Letras das Faculdades Integradas de Uberaba, 1984. 
PÊCHEUX, Michel. Análise Automática do Discurso. In: GADET, F.; HAK, T.; (Orgs.). Por uma análise automática do discurso: uma introdução à obra de Michel Pêcheux. Tradução de Bethania Mariani [et al.], 3a ed., Campinas: Editora da UNICAMP, 1997a.

PÊCHEUX, Michel. Semântica e discurso: uma crítica à afirmação do óbvio. Tradução de Eni Puccinelli Orlandi [et al.], 3a ed., Campinas: Editora da UNICAMP, 1997b.

PÊCHEUX, Michel; GADET, F. A língua inatingível: o discurso na história da lingüística. Campinas: Pontes, 2004.

PINTO, Luiz Maria da Silva. Diccionario da Lingua Brasileira. Ouro Preto: Typographia de Silva, 1832.

PIZARROSO, Alejandro. Historia de la propaganda: Notas para un estudio de la propaganda política y de guerra. Madrid: Eudema, 1993.

QUEBRADA, Linn da. Oração. Intérpretes: Linn da Quebrada, Liniker, Urias, Alice Guél, Jup do Bairro, Danna Lisboa, Ventura Profana \& Verónica Decide Morrer. 2019.

SILVA, Pollyanna Honorata. Classificados: um gênero jornalístico descritivo. Estudos Lingüísticos XXXVI, setembro-dezembro, 2007, pp. 210-216.

SOUSA, Cruz e. Obra completa: poesia. João da Cruz e Sousa (Org.). Jaraguá do Sul: Avenida, 2008. v. 1 (612 p.).

SOUSA, Jorge Pedro. Elementos de jornalismo impresso. Porto, 2001. Disponível em: http://bocc.ufp.pt/pag/sousa-jorge-pedro-elementos-de-jornalismo-impresso.pdf. Acesso em: 10 set 2019.

TEIXEIRA, M. C.; VALLA, M. O urbanismo português. Séculos XIII-XVIII PortugalBrasil. Lisboa: Livros Horizonte, 1999.

TRAQUINA, Nelson. Teorias do Jornalismo. A tribo jornalística - uma comunidade interpretativa transnacional. Volume I. Florianópolis: Insular, 2005.

Data de Recebimento: 04/14/2019

Data de Aprovação: 05/02/2020 
Para citar essa obra:

AMARAL, João Flávio Menezes; RODRIGUES, Isadora Meneses. Gentrificação, mídia e poder simbólico: reflexões sobre o consumo do espaço urbano mercantilizado Ética e argumentação abolicionista: (anotações a um texto de José do Patrocínio). In: RUA [online]. Volume 26, número 1 - Ahead of print - e-ISSN 2179-9911 -jun./2020. Consultada no Portal Labeurb - Revista do Laboratório de Estudos Urbanos do Núcleo de Desenvolvimento da Criatividade. http://www.labeurb.unicamp.br/rual

Capa: Figura 1 - Fac-símile do DRJ a $1^{\circ}$ de setembro de 1828 . Fonte: Hemeroteca Digital da Biblioteca Nacional do Brasil

Laboratório de Estudos Urbanos - LABEURB

Núcleo de Desenvolvimento da Criatividade - NUDECRI

Universidade Estadual de Campinas - UNICAMP

http://www.labeurb.unicamp.br/

Endereço:

LABEURB - LABORATÓRIO DE ESTUDOS URBANOS

UNICAMP/COCEN / NUDECRI

CAIXA POSTAL 6166

Campinas/SP - Brasil

CEP 13083-892

Fone/ Fax: (19) 3521-7900

Contato: http://www.labeurb.unicamp.br/contato 